Remount Depôt of 10,000 acres and nearly 3,000 horses and mules, is a very up-to-date district. In another respect, it is a remote out-of-the-way district, in which there are only 4,600 boys receiving a secondary standard of education, and not one girl, out of a total population of 687,000 ; in which the birth-rate and death-rate in the decennium ending in 1910 were respectively 45 and 47 per mille; in which testamentary dispositions are almost entirely unknown; in which most of the agricultural rents are grain-rents; and in which manual workers pay a polltax to their zamindars, who in fifty-seven of the villages are also entitled to a feudal cess on marriage. The Musalmans comprise 83 per cent of the population, but in their customs of inheritance they follow the principles of agnatic relationship rather than the rules of Shariat. They practically compose the whole of the agricultural and artisan classes. They are, however, organized on the tribal system. The Tiwánas fill a very large part in the history of the district, and the leading Tiwana families deservedly occupy a prominent place in the social, military, agricultural, and administrative life of the Province. The Gazetteer gives a fascinating account of these and other families. Mr. Leigh, who wrote it, drew largely on the account written by Sir James Wilson in 1897. "He modestly calls his own work "patch-work", but a perusal of such a local account brings us more closely into touch with the bed-rock facts of Indian life than more generalized works.

A. Y. A.

\title{
ISLAM AND SCIENCE ${ }^{1}$
}

Renan's address on "L'Islamism et la Science" is beginning to attract the attention of the Muslim world.
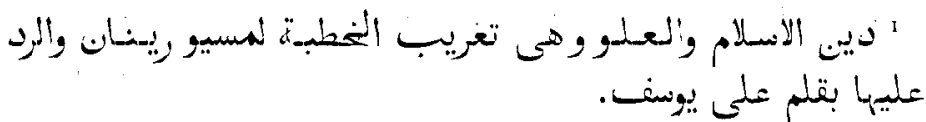
Mr. A. Yusuf, author of the History of Arabic Mathematics and Astronomy and Life and Philosophy. of Al Ghazzali, has published at Cairo an Arabic translation of the address, with a refutation of it from a Muslim point of view. Part of the refutation consists in the account of the life and philosophy of Renan, which Mr. Yusuf has prefixed to his translation. He considers it significant that Renan should have found it impossible to reconcile his own ancestral faith with his philosophy. He draws a parallel between Al-Gazzali and Renan. Gazzáli, he says, first mastered philosophy and the sciences, but found that they did not satisfy the thirst of his soul, and he eventually found his restingplace in Islam. Renan, on the other hand, found no satisfaction in his ancestral faith, and had to abandon it and find his resting-place in philosophy.

A. Y. A.

Promotion of Learning in India during Muham madan Rule (by Muhammadans). By Narendra Nath Law. With illustrations. Longmans Green, 1916.

"The contributions to learning and culture made by Islam in India," says Mr. Henry Beveridge, who contributes a Foreword, "are indeed worthy of a special consideration." It was a task well worth doing, to collect together all. the notices bearing on the subject to be found in the historians of Muhammadan India. Mr. Law has carried out this task comprehensively and in the spirit of a scholar. Indeed, he has cast his net widely, and included among his authorities even the pictorial record of a cold weather tour by my late friend Mr. W. S. Caine, M.P., whose interest in the people of India covered a much wider ground than their modern political activities. 